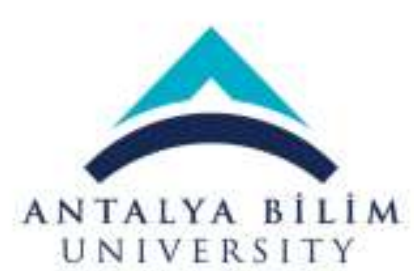

UNIVERSITY

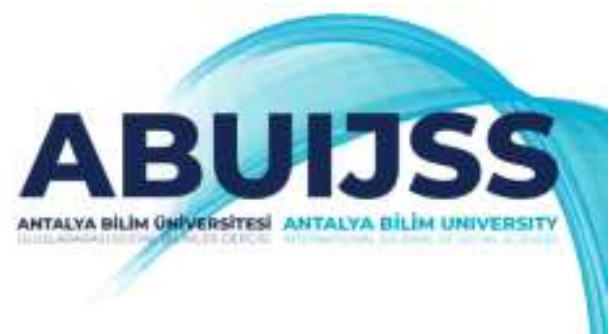

\title{
AN EVALUATION OF IMPACT OF ADVERTISING INTENSITY ON ENTRY MODE CHOICE
}

\author{
Cem KARAYALÇIN*
}

\begin{abstract}
Globalization has led companies to expand into foreign markets. These multinational enterprises (MNEs) consider diverse factors when entering a foreign country. One of the important decisions the MNEs make is the entry mode choice. Additionally, advertising intensity can be another important factor that may affect the entry mode choice. Therefore, it is important to make an analysis regarding the effect of advertising intensity on entry mode choice. Accordingly, the aim of this study is to make an evaluation regarding the impact of advertising intensity on entry mode choice. Six articles were chosen that are related to this topic to make a such investigation. The result of the evaluation showed that there are some inconsistent findings in the literature that are discussed in the paper. Apart from the inconsistencies, it can be stated that as the advertising intensity increases, the MNEs may choose wholly owned subsidiary to enter a foreign market.
\end{abstract}

Key Words: Entry mode choice, joint venture, wholly owned subsidiary, advertising intensity, marketing Type of article: Research

Jel Classification: M10, M31, M37

DOI: 10.54969/abuijss.1027053

Received: 22.11.2021 / Accepted: 15.12.2021 / Published: 31.12 .2021

\section{REKLAM YOĞUNLUĞUNUN PAZARA GIRIŞ STRATEJISINE ETKISI ÜZERINE BIR DEĞERLENDIRME}

Öz: Küreselleşme şirketlerin yabancı pazarlara yönelmesinde etkili olmuştur. Çok uluslu şirketler yabancı bir ülkeye girerken çeşitli faktörleri değerlendirmektedir. Bu bağlamda verilmesi gereken önemli bir karar pazara giriş stratejisidir (giriş modu tercihi). Buna ek olarak reklam yoğunluğu da pazara giriş stratejisini etkileyebilecek önemli bir faktördür. Bu nedenle, reklam yoğunluğunun pazara giriş stratejisine olan tesiri üzerine bir analiz yapmak önem taşımaktadır. Bu çalışmanın amacı reklam yoğunluğunun pazara giriş stratejisine olan etkisi konusunda bir değerlendirme yapmaktır. Belirtilen incelemeyi gerçekleştirebilmek için ilgili konudaki altı makale seçilmiştir. Yapılan değerlendirme sonucunda literatürde tutarsız bulguların olduğu gözlemlenmiş olup, konu ile ilgili detaylar makalede tartışılmıştır. Tutarsızlıklara rağmen, genel anlamda, reklam yoğunluğu arttıkça çok uluslu şirketlerin tamamına sahip olunan bağı ortaklık ile yabancı pazara giriş yapma ihtimalinin arttığı çıkarımı yapılabilmektedir.

Anahtar Kelimeler: Pazara giriş stratejisi, ortak girişim, tamamına sahip olunan bağlı ortaklık, reklam yoğunluğu, pazarlama

Makalenin türü: Araştırma

Jel Sınıflandırması: M10, M31, M37

DOI: 10.54969/abuijss.1027053

Geliş tarihi: 22.11.2021/ Kabul Tarihi: 15.12.2021/ Yayın Tarihi: 31.12.2021

* Dr. Öğr. Üyesi, Antalya Bilim Üniversitesi, Antalya, cem.karayalcin@antalya.edu.tr, ORCID: 0000-0002-0847-8020 Kaynak gösterimi için:

Karayalçın, C. (2021). An Evaluation of Impact of Advertising Intensity on Entry Mode Choice. Antalya Bilim University International Journal of Social Sciences, 2 (2), 118-126. DOI: 10.54969/abuijss.1027053 


\section{INTRODUCTION}

As the name implies, multinational enterprises (MNEs) seek to enter foreign markets outside their national market. There may be several reasons to expand foreign market such as capturing new consumers, extending market share, creating economies of scale and so on. Although there are several advantages of having an investment to another country, there are also some risks mainly because of the high amount of capital being invested. In order to eliminate some of the financial risks, MNEs should carefully make plans regarding how to expand abroad. One important aspect of expanding abroad is the choice of entry mode. In the literature, there are articles that examined different types of entry modes. MNEs can enter to a foreign market through either acquiring a local firm, or with greenfield investment (Hennart and Park, 1993). Kumar and Subramanian (1997) shows a hierarchical model of the mode of entry decision such as equity modes (joint venture, acquisition, greenfield), and non-equity modes (exporting and contractual agreements). However, other literature (Hennart and Park, 1993; Anand and Delios, 2002; Cheng 2006; Gilroy and Lucas, 2006; Gomes-Casseres, 1989; Hennart, 1991; Fladmoe-Lindquist and Jacque, 1995; Chen and Hennart, 2002; Tsang, 2005; Gatignon and Anderson, 1988; Hill et al., 1990) investigated entry modes such that (i) greenfield or acquisition, (ii) licensingfranchising-joint venture (JV) or wholly owned subsidiary (WOS) and with respect to the level of control (high-low) of the subsidiary. Considering entry mode of choice, Hennart (1988) also makes the distinction between establishment mode choice and ownership structure of the firm. So when entering a foreign market, it is important for MNEs to decide the entry mode choice with respect to ownership structure such as entering with JV or WOS, high control modes or low control modes and so on. One of the important variables that might affect this decision is advertising intensity. As one of the most important marketing phenomena, advertising is a crucial factor that can influence the success of an investment. For instance, if there is high adverting intensity in an industry, the company may want to use it's brand asset and protect it by entering with WOS (Fladmoe-Lindquist and Jacque, 1995). Moreover, there are also recent papers that are published in highly regarded journals including the topics entry mode choice (e.g. Li et al., 2021; Mariotti et al., 2021) and advertising intensity (e.g. Tripathi et al., 2020; Fan et al., 2021). Accordingly it is important to make an evaluation regarding the effect of advertising intensity on entry mode choice. The main aim of this paper is to examine the literature regarding the effect of the advertising intensity to the entry mode choice with respect to ownership structure of the firm. By analyzing different articles, it is also aimed to investigate whether there are consistent results regarding the effect of advertising intensity on entry mode choice. In addition to this, this paper aims to help researchers by suggesting new topics in this field. Moreover, big MNEs spend millions of dollars for their total advertising/marketing budget every year which makes it very important for managers to come up with the optimal decision considering the entry mode of choice. By evaluating the advertising intensity on entry mode choice, the current paper tries to enlighten the literature and practical business life in that manner.

This paper will continue with selection of the articles that will be evaluated. Next, theories of the papers will be discussed, then hypotheses, data, and findings of the articles will be elaborated. The last section of the paper provides a general discussion and conclusion of the study including future research directions and limitations of the study. 


\section{Literature Review}

\subsection{Articles Included in the Study}

As mentioned above, there is different academic literature that investigated the entry mode of choice of MNEs in different terms. In order to evaluate the literature regarding impact of advertising intensity on entry mode choice, it is attempted to conduct a longitudinal approach. In the first phase, it is found that articles are mostly from the years 1980 's, 1990's, and 2000's. There were also articles that are contextually similar but the specific topic is somewhat different. These articles were excluded from the study, for instance; Hennart and Park (1993), Gilroy and Lukas (2006) and Anand and Delios (2002) which investigated acquisitions vs. greenfield; Cheng (2006) that compared acquisitionsbrownfield-greenfield; Singh and Kogut (1989) which analyzed acquisitions-JVs-wholly owned greenfield. MNEs can enter to foreign market either with acquisitions or greenfield investments which will be followed by the decision of the ownership structure which can be JVs, WOS, licensing, franchising and so on. In that perspective, two articles that belongs to 1980's, 1990's, and 2000's were chosen randomly to be included in the study. Three of them (Gomes-Casseres, 1989; Chen and Hennart, 2002; Hennart, 1991) investigated JVs vs WOS; Fladmoe-Lindquist and Jacque (1995) compared franchising vs WOS; Tsang (2005) investigated BCC (business corporation contract) vs EJVs (equity joint ventures) vs WOS and Gatignon and Anderson (1988) explored the decision of the entry mode with regard to lowhigh control mode. As mentioned by Hill et al. (1990), licensing has lowest control; WOS has highest, and JVs lies in the middle. In the paper of Gatignon and Anderson (1988), it is not explicitly mentioned which entry mode of choice was used such as JV or WOS; so that this paper also considers entry mode of choice with respect to high-low control entry modes. To classify the entry modes of Gatignon and Anderson's (1988) article, Hill's et al. (1990) approach will be used in this paper; that is high control indicates WOS. Another important point to mention is that Gomes-Casseres's (1989) article investigated the effect of marketing intensity (not advertising intensity) on entry mode choice (JV or WOS), however, this article is also included in this paper since it is a highly relevant and important article. Since advertising is one most important factors of marketing, this article is also considered in the current research - an evaluation regarding the effect of advertising intensity on entry mode choice. To sum, six articles were analyzed for this paper and it is seen that the common entry mode is WOS among the six studies.

\subsection{Theories of the Articles}

Apart from the articles included in the study, one related theoretical paper (i.e. Hill et al., 1990) is also explanatory regarding the theories used in the articles. All papers except Chen and Hennart (2002) include transaction cost theory when explaining the theoretical background (related to advertising/marketing intensity) of their papers. Transaction cost theory deals with problem of how an MNE should balance its boundary activities with other firms; and minimizing the transaction and production costs when deciding the entry mode choice (Tsang, 2005). Gomes-Casseres (1989) states that marketing skills are often the main aspect of the industry specific advantages. When entering to foreign market, MNEs should consider all the costs associated with the transaction costs and should try to benefit of the industry specific advantages with the optimal entry mode. Tsang (2005) also adds that there are ownership advantages such as well-known brand name which is also part of marketing 
aspect of a firm. While there are some advantages, Hennart (1991) indicates that there are also costs that should be balanced with sharing ownership (joint ventures) relative to those of full ownership (WOS). Advertising of the firm and industry could sometimes be an advantage; however, it may also have some drawbacks if the firm enters to the foreign market with wrong entry mode. As the advertising intensity increases, Hennart (1991) and Tsang (2005) indicates that it will be much more beneficial to enter foreign market by WOS. Entering with WOS will reduce transaction costs associated with advertising intensity.

Hill et al. (1990) approaches to the transaction cost theory (or the internalization theory) by underlying the importance of the firm specific advantages in know-how (e.g. marketing know-how); and in the light of this theory, MNEs that have transaction costs will favor WOS. Advertising/marketing know-how is not absent for many of the MNEs so they should consider the choice of entry mode carefully. Hennart (1991) adds by indicating MNEs differentiating their products by advertising should continue with WOS. If the brand name and the company image is very important in the industry, JV partner can free ride with the reputation by using all benefits of the brand; and having really low costs; the firm can overcome the problem with WOS (Fladmoe-Lindquist and Jacque, 1995; Hennart, 1991; Gatignon and Anderson, 1988). Gatignon and Anderson (1988) also mentions that MNEs entering with WOS will get the highest control over subsidiaries comparing with the other alternatives such as JVs, licensing, franchising and BCC. With higher control, the parent MNE can easily control the subsidiaries and reduce the transaction costs; share benefits of the name of the brand (reputation) equally and for its own.

Hill et al. (1990) refers to the dissemination risk which is the risk that firm specific advantages will be used opportunistically by the licensing or joint venture partner. Moreover, they state that firms should try to protect firm specific know how (such as advertising/marketing) to be disseminated because if that happens, it would reduce the quasi-rents that could be earned from the know-how. As the quasi-rents increases, the risk of acting opportunistically by the partner increases. MNEs will try to limit opportunism which will lead high transaction costs. In that case, the MNE can decrease the costs by favoring WOS (Hill et al., 1990). Tsang (2005) states that when the foreign partner contributes a wellknown brand to EJV located in an emerging economy where the legal infrastructure is often less developed, the local partner may act opportunistically. WOS is again the optimal solution to prevent this problem. Chen and Hennart (2002) use the theory of barriers to entry and stating that advertising intensity of the home-host business will also measure the barriers of entry. In addition, as the advertising intensity increases, the cultural barriers will be industry specific and MNEs will be less likely to choose WOS, which is different than the theory of the transactional cost view.

\subsection{Hypotheses, Data, and Findings of the Articles}

As it was mentioned before, the common entry mode of all articles is WOS. In order to group the hypotheses of the articles, it is suitable to mention the related hypotheses on a common ground. Accordingly, the papers used the theory of transaction cost theory (Gomes-Casseres, 1989; Fladmoe-Lindquist and Jacque, 1995; Hennart, 1991; Tsang, 2005; Gatignon and Anderson, 1988) predict a positive relationship by entering with WOS. So, as the advertising intensity increases, the MNE will probably enter to the foreign market by WOS. Chen and Hennart (2002) predict a negative relationship with WOS on the other hand. 
This one negative relationship may be due to the different approach of theory used in the literature.

Considering the data used in the papers, Gatignon and Anderson (1988) used one of the largest scaled and longest period of time data which is 180 largest American companies and over 19,000 foreign subsidiaries from 1900 to 1975. The basis of their data were from Harvard Multinational Enterprise Project, which came from published resources, corporate directories, corporate annual reports that was also checked by business press reports and interviews with multinational corporation management. Hennart (1991) and Chen and Hennart (2002) used Japanese manufacturing subsidiaries entering U.S. where Chen and Hennart (2002) collected data from Toyo Keizai in 1987 and Japanese Economic Institute from 1981 to 1989 including sample size of 269 affiliates. Hennart (1991) collected data from a survey including 158 observations which is from 1985 (Toyo Keizai 1987). Tsang (2005) used mostly food and beverages, fishing, textiles, hotel, and some manufacturing companies entering Vietnam and the data was from 1988 to mid-2000, The List of Licensed Projects that is published by the Ministry of Planning and Investment of Vietnam. Gomes-Casseres (1989) got data from multiple sources such as Harvard's Multinational Enterprise Project, PIMS database, World Bank statistics, surveys by the U.S. Departments of Commerce, and Stopford and Wells containing 1,532 observations. A similarity between Tsang (2005) and Gomes-Casseres (1989) is that both used some companies from chemical industries and include various nations from Europe. Lastly, Fladmoe-Lindquist and Jacque (1995) had a sample from service firms such as hotel, restaurant, and retail services which was selected from reports such as United Nations report on international services (UNCTC 1989), joint research project between Columbia University and United Nations and trade reports on international retail expansion by American firms. One common point regarding the data of Fladmoe-Lindquist and Jacque (1995) and Tsang (2005) is that both included data from hotels.

When the results of the articles were evaluated, it can be seen that the findings of the papers are somehow inconsistent with one another. Gomes-Casseres (1989) found that as the marketing intensity (also considered as advertising intensity for this study) of the industry increases, entering with WOS increases over JV as expected. Fladmoe-Lindquist and Jacque (1995) observed that advertising intensity has a positive effect to enter with WOS over franchising. In addition, Gatignon and Anderson (1988) found that high control modes (WOS) are favored as the advertising intensity of the product increases. On the other hand, in some of the models, Tsang (2005) concluded that as the advertising intensity of the industry increases, the probability of entering with WOS decreases compared to EJV. Hennart (1991) and Chen and Hennart (2002) also observed that as the advertising intensity increases in the host market, firms do not enter with WOS; however, the result of Hennart (1991) is insignificant which means that there is not a clear effect of advertising intensity to the mode of entry. There are some inconsistent causal relationships between advertising intensity and the entry mode choice among the empirical findings of the papers. Half of the articles found positive relationship between advertising intensity and entering with WOS, while others' findings show either negative or insignificant relationships. 


\section{Discussion and Conclusion}

For the last decades, it can be said that globalization has made the boundaries between national borders more transparent and companies have been entering foreign markets. These MNEs need to decide on many factors when planning their expansion strategy. Entry mode choice is one of the important decisions of MNEs. Regarding entry mode decision, advertising intensity is another factor that might affect the entry mode choice. In that respect, the main objective of this paper was to make an evaluation regarding the effect of advertising intensity on entry mode choice considering ownership structure. To make a such evaluation, articles containing the relevant topic with an empirical approach were analyzed based on their theoretical approach, hypotheses developed, data used and empirical results.

Considering the empirical findings of the articles, half of the papers found different causal relationships between advertising intensity and entry mode choice. The results of the articles showed that while Gomes-Casseres (1989), Fladmoe-Lindquist and Jacque (1995), and Gatignon and Anderson (1988) found out a positive relationship between advertising intensity and the probability of entering with WOS, the findings of Tsang (2005), Hennart (1991), and Chen and Hennart (2002) are contradicting with the first three articles' results. There is a clear inconsistency with the results. The inconsistency may be caused because of several factors. First, Hennart (1991) and Chen and Hennart (2002) observed Japanese subsidiaries in U.S. which may explain having different empirical findings because Japanese firms are quite different than U.S. firms in terms of culture, working routines, hierarchy and so on. Secondly, Tsang (2005) observed various countries entering Vietnam, which can be considered as an emerging economy. Emerging economies may produce different results because the common theories and practices might not be suitable for these kinds of economies so that some of the findings may be diverse. Lastly, Hennart (1991) and Chen and Hennart (2002) focused on manufacturing companies which Tsang (2005) also included some samples from that industry. The negative or insignificant relationships may also be caused by industry specific reasons. Nevertheless, since Hennart's (1991) finding was insignificant and the half of the articles found a positive relationship with advertising intensity and entering with WOS, as a conclusion, it can be inferred that as the advertising intensity increases, the probability of entering with WOS also increases. Therefore, if there is high advertising intensity, the MNE may want to have more control regarding its marketing communication efforts so that entering with WOS increases.

There are also some important suggestions for future research based on the articles. Fladmoe-Lindquist and Jacque (1995) investigated services sector as a whole (e.g. retail, restaurants, hotel) and concluded that there is a negative effect to franchise over entering wholly owned as the advertising (reputation-brand name) intensity increases. To understand the clear effect of advertising intensity to the entry mode choice, a new research regarding the impact of advertising intensity to the entry mode choice among franchisinglicensing-JV-WOS in retail sector could be beneficial for practical life. This is because for retail sector, the importance of brand name may be different compared to other service sectors; so the new research may provide crucial information. As explained in the theories of the articles section, a theoretical paper (i.e. Hill et al., 1990) was also included in the study to contribute to the explanation of the theories of the chosen articles. In their article, Hill et al. (1990) concludes that WOS is favorable in knowledge intensive industries and when the global industry is characterized by oligopolistic interdependence. Another interesting new 
research topic might be the effect of advertising intensity to entry mode choice in an industry which is not knowledge and oligopolistic based. In such industry, the expected and desired entry mode choice might be different. Therefore, with this new research, the impact of the advertising intensity on the entry mode choice can be observed much more specifically. Hennart (1991) and Chen and Hennart (2002) investigated Japanese manufacturing MNEs entering U.S. and found either negative or insignificant effect of advertising intensity on entering with WOS. Future research may look at MNEs from countries having similar cultures with Japan entering to U.S. to observe whether the negative and insignificant effect were actually caused by cultural differences.

The current paper has also some limitations that brings some other future research directions. First of all, one of the articles included in the study is not specifically exploring advertising intensity but marketing intensity. Since advertising is one of the most important aspects of marketing, this article is also considered in the study. The future research could evaluate articles that are more precise regarding the effect of advertising intensity on entry mode choice. Secondly, the current paper analyzed six articles in order to explore the related topic, which were randomly selected from 1980's, 1990's, and 2000's. It is recommended that future papers could evaluate the same topic containing more recent articles and also having a more considerable number of studies. This will provide additional information regarding the topic. Finally, as another interesting future research topic, to observe the actual performance of the entry mode choice, one can look to the effect of advertising intensity on the entry mode choice and the performance of the subsidiaries. By analyzing the actual performance through taking into account the advertising intensity, the results may more accurately demonstrate whether the choice of entry mode has been optimal, which is another important topic for further research. 


\section{References}

Anand, J. \& Delios, A. (2002). Absolute and relative resources as determinants of international acquisitions. Strategic Management Journal, 23, 119-134.

Chen, S.-F. S. \& Hennart, J.-F. (2002). Japanese investors' choice of joint ventures versus wholly-owned subsidiaries in the US: The role of market barriers and firm capabilities. Journal of International Business Studies, 33(1), 1-18.

Cheng, Y.-M. (2006). Determinants of FDI mode choice: Acquisitions, brownfield, and greenfield entry in foreign markets. Canadian Journal of Administrative Sciences, 23(3), 202-220.

Fan, D. \& Xiao, C. \& Zhang, X. \& Guo, Y. (2021). Gaining customer satisfaction through sustainable supplier development: The role of firm reputation and marketing communication. Transportation Research Part E, 154, 102453.

Fladmoe-Lindquist, K. \& Jacque, L. L. (1995). Control modes in international service operations: The propensity to franchise. Management Science 41(7), 1238-1249.

Gatignon, H. \& Anderson, E. (1988). The multinational corporation's degree of control over foreign subsidiaries: An empirical test of a transaction cost explanation. Journal of Law, Economics, Organization, 4(2), 305-336.

Gilroy, B. M. \& Lukas, E. (2006). The choice between greenfield investment and cross-border acquisition: A real option approach. The Quarterly Review of Economics and Finance, 46(3), 447-465.

Gomes-Casseres, B. (1989). Ownership structures of foreign subsidiaries: Theory and evidence. Journal of Economic Behavior and Organization, 11, 1-25.

Hennart, J.-F. (1988). A transaction costs theory of equity joint ventures. Strategic Management Journal, 9(4), 361-374.

Hennart, J.-F. (1991). The transaction costs theory of joint ventures: An empirical study of Japanese subsidiaries in the United States. Management Science, 37(4), 483-497.

Hennart, J.-F. \& Park, Y.-R. (1993). Greenfield vs. acquisition: The strategy of Japanese investors in the United States. Management Science, 39(9), 1054-1070.

Hill, C. W. L. \& Hwang, P. \& Kim, W. C. (1990). An eclectic theory of the choice of international entry mode. Strategic Management Journal, 11(2), 117-128.

Kumar, V. \& Subramanian V. (1997). A contingency framework for the mode of entry decision. Journal of World Business, 32(1), 53-72. 
Li, Y. \& Zhang, B. \& Fan, D. \& Li, Z. (2021). Digital media, control of corruption, and emerging multinational enterprise's FDI entry mode choice. Journal of Business Research, 130, 247-259.

Mariotti, S. \& Marzano, R. \& Piscitello, L. (2021). The role of family firms' generational heterogeneity in the entry mode choice in foreign markets. Journal of Business Research, 132, 800-812.

Singh, H. \& Kogut, B. (1989). Industry and competitive effects on the choice of entry mode. Academy of Management Proceedings, 116-120.

Tripathi, S. N. \& Misra, D. \& Siddiqui, M. (2020). Impact of advertising intensity on market risk of a firm: A study on the Indian consumer goods sector. Global Business Review, 21(6), 1376-1386.

Tsang, E. W. K. (2005). Influences on foreign ownership level and entry mode choice in Vietnam. International Business Review, 14, 441-463. 